\title{
TURNING THE TIDE: REVISITING AFRICAN MARITIME SECURITY
}

\author{
Francois Vrë̈ \\ Stellenbosch University
}

\begin{abstract}
Maritime security appears to be assuming an increasingly more prominent place on the African security agenda. Although the growing scholarly debate and international responses seem to attend to more than piracy, the latter unfortunately skews perceptions about Africa's maritime landscape. The piracy focus suggests a limited problem-solving approach, but Africa's offshore domain calls for a more critical stance that entails more than anti-piracy. Perceptions and realities of maritime terrorism, piracy, illegal oil bunkering, criminality and unsettled maritime boundaries increasingly complicate traditional African threats and vulnerabilities on land. The growing range of threats requires a framework to explain events taking shape off West and East Africa in particular better. In this regard, the constituent elements of good order at sea house a more critical line to view security off Africa through safe access to resources (food and minerals), safe sea routes, as well as dominium and jurisdiction. Opposition to threats off the African coast tends to privilege naval responses, but closer scrutiny reflects that responses are found to also display a profile of cooperation between numerous actors and agencies that securitise maritime threats beyond piracy. The resultant cooperation reveals landward and offshore initiatives that promote maritime security, rather than merely fighting piracy.
\end{abstract}

\section{Introduction}

Although African leaders attempt to counter pessimistic perceptions of Africa, ${ }^{1}$ an array of threats and vulnerabilities co-exist alongside narratives that depict the continent in a more positive light. ${ }^{2}$ While negative images of the African security landscape mostly stem from events on land, offshore threats are competing

Scientia Militaria, South African Journal of Military Studies, Vol

$41, \mathrm{Nr} 2,2013$, pp. 1-23.

doi : $10.5787 / 41-2-1065$ with the landward security emphasis. Views of Africa as a haven for pirates help to skew understanding of the African maritime threat landscape by identifying piracy as the key to restore good order at sea. The emergent 
African maritime security debate must be taken seriously, as the world's oceans offer a most lucrative operating environment to terrorists and criminals, which comprises more than a piracy threat. ${ }^{3}$

Recent literature on maritime threats and vulnerabilities emphasises the Africa piracy nexus, but the wider maritime security sector requires closer attention as well. This article contributes to the debate on Africa's maritime security by accentuating the wider ambit of threats and responses that now embody African maritime security. To this end, the narrative attempts to move the argument beyond problem-solving theory centred on suppressing piracy to a more critical stance based on constituent elements of good order at sea as the preferred condition off the African coast.

Upholding the constituent elements of good order at sea, extending maritime security beyond piracy and events on land, and the imperative of security agency cooperation form the central thesis of the article. The geographic focus covers primarily the waters off the eastern and western seaboards of the continent, although the narrative also touches upon events along the Mediterranean and Southern African coastlines. The argument commences with the growing realisation of the importance of Africa's maritime domain. Secondly, the narrative outlines emergent sectors of Africa's maritime security and the threats that manifest in events unfolding off West and East Africa. Having established the insecurities in African waters, the third and final section turns to the range of actors and activities employed against maritime threats along the western and eastern seaboards of Africa.

\section{An emergent African maritime consciousness?}

A pattern of explicit commitments to secure African offshore assets is a rather recent manifestation. One tentative argument for the somewhat low-keyed African maritime strategies posits the presence of a landward culture within the African strategic outlook and one reinforced by a perception of maritime threats not endangering regime security. ${ }^{4}$ Heuser, quoting Corbett, argues that the term 'maritime strategy' in fact presumes a reciprocal land-sea nexus in operations, and she flags the danger of neglecting either one. Maritime strategy ideally ties operations at sea to events on land as the former rarely makes sense if its relationship with or impact upon land is ignored. ${ }^{5}$ Against the former backdrop, any disregard of offshore threats thus sets a dangerous precedent and one coming of age along sections of the African coast.

To privilege landward over offshore threats and vulnerabilities merely cultivates conditions for greater threats from the sea. The perceived African 
ambivalence either stems from them not fully embracing the importance of a secure offshore domain, or a deliberate ignorance to attend to matters on land. A lack of governance by African authorities to uphold sovereignty in the waters under their jurisdiction is accentuated by weak African navies due to the latter not being considered as important as armies. ${ }^{6}$ Addressing the landward security preference supposes shifting a preferred security culture to one also responsive to maritime security threats and vulnerabilities. ${ }^{7}$ Such a shift takes time and it is therefore essential to point out some indicators of an emergent African maritime disposition.

Covering a coastline of 26000 kilometres, the African maritime territory is huge. The aforementioned length includes the seabed below and the airspace above, all of which add to the maritime sphere over which African coastal states (according to the Preamble of the United Nations Convention of the Sea) are required maintain jurisdiction. ${ }^{8}$ Thirty-three coastal states and several islands like Madagascar, Mauritius, Seychelles, and São Tomé \& Príncipe, accentuate the scope of maritime matters and security in particular. Fifteen landlocked African countries are also dependent upon secure maritime zones, and as the second most densely populated continent, African maritime threats and vulnerabilities hold dire risks for the large African population. ${ }^{9}$

Africa's oceans harbour important resources and lines of communication that call for protection, and if necessary, more aggressive defence. Globalisation and its economic pillar in particular - relies on African waters as cogs in the safe flow of maritime traffic along international shipping routes. African co-operation to safeguard the maritime commons is imperative. ${ }^{10}$ The oceans also tie Africa into global maritime trading and industrial networks that hold critical strategic advantages for Africa as well as the wider international community, as the continent becomes a future economic entity for markets, labour and resources. Fishing resources off Africa are also popular with the international community, not ignoring the fact that millions of Africans depend upon fish as their staple source of protein. As a rising energy actor, Africa's growing offshore energy assets drive its role as a future gas and oil hub. ${ }^{11}$ The continent's global importance is thus also growing due to its valuable, but vulnerable maritime landscape - a domain for which it rarely receives due recognition, but one to which it is awakening.

A shift in the scholarly literature since approximately 2005 highlights maritime matters in the debate on African security. ${ }^{12}$ Although piracy and marine resources form a primary focus of the literature, the scholarly contributions dovetail with indicators of a growing African maritime awareness. Acceptance by African Union Transport Ministers of the African Maritime Transport Charter and action plan (October 2009), as well as a resolution on maritime safety, security and 
protection of the African marine environment shows an African concern with maritime security. ${ }^{13}$ During 2010, the African Union (AU) opted to pursue an integrated African maritime strategy (briefly known as AIMS 2050) that signifies further progress. ${ }^{14}$ In addition to the AIMS 2050 declaration, the Brenthurst Discussion Paper No 3 of 2010 outlines a comprehensive NGO (non-governmental organisation) view on an Africa-informed maritime strategy. ${ }^{15}$ At the sub-regional level, the 2011 Heads of State Summit of the Southern African Development Community (SADC) in Luanda accepted a maritime strategy to fight piracy along the African eastern and western shores respectively. ${ }^{16}$ African navies also play a role since 2005 through the biennial Sea Power for Africa symposia to sensitise their governments and ultimately the AU through resolutions emphasising Africa's oceans, its resources, those who live from the oceans and thus the need to protect the seas. ${ }^{17}$ The aforementioned developments flag a recent pattern of African responses to maritime vulnerabilities that says something about a declaratory shift away from a period of self-imposed sea blindness. ${ }^{18}$ Securing the seas off Africa is unfortunately not simple as preserving good order at sea taxes even modern navies. ${ }^{19}$ However, irrespective of the difficulties involved, the constituent elements of good order at sea outlined below require closer attention from African leaders for these elements still serve as the mainstay of order off coastal and island states.

The scope and importance of oil and gas resources at sea are growing rapidly and threats to these hubs draw international attention. ${ }^{20}$ West African waters harbour impressive new discoveries of oil and gas, but also dangerous criminal and insurgent threats. ${ }^{21}$ New and lucrative oil and gas deposits off Africa are bound to accentuate the importance of certain maritime zones (including the seas off eastern Africa), and securing such locations is important for Africa and its growing list of trade partners. The McKinsey Report of 2010, for example, alludes to the particular role of oil and gas in promoting Africa's future growth, and such optimism only serves to reinforce Africa's need to secure safe access to its significant offshore oil and gas deposits. ${ }^{22}$

The African fishing industry provides a livelihood for large numbers of people and the prevention of illegal and unregulated fishing is crucial. Recent warnings, such as "The end of the line" documentary programme, clearly accentuate pressures upon fishing stocks. Over- and illegal fishing practices are a clear and present threat to food resources and one not sparing Africa, but also receiving insufficient attention. Piracy off Somalia allegedly mutated from local attempts to curb illegal fishing, while dangerous transgressions also take place off West Africa with its huge local fishing culture. ${ }^{23}$ Securing the ocean off Africa as a source of food and thus promoting food security for vulnerable coastal populations in particular call for more Africa-led initiatives. 
Secure maritime transport routes are vitally important to the international community, and Till accentuates the fundamental role of safe maritime transport routes for the globalised world of the $21^{\text {st }}$ century. ${ }^{24}$ Given the volume of goods that flow by sea (irrespective of speculations, the volume remains impressive), the safety and security of maritime routes must concern all governments. The density of shipping along the African coastline (through the Gulf of Aden, around the southern tip and in the Gulf of Guinea) implies that African governments can barely afford the maritime ignorance and/or institutional incapacity they display at times. ${ }^{25}$ As Africa enters the global economy as an attractive investment destination and resource hub, every African country depends increasingly on the free and uninterrupted flow of trade across the oceans to benefit from the economic advantage to deliver goods on time to and from Africa. Africa can thus ill afford the current uncertainty tainting shipping routes off sections of the West and East African seaboards.

Jurisdiction over the oceans comprises a national and international responsibility. Both have legal grounding, but questionable enforcement off Africa in particular. Good governance over the ocean requires that each country extends effective rule over its territorial waters and that the international society collaborates to maintain order on the high seas. ${ }^{26}$ Such national and international responsibilities imply home and away deployments for navies in particular, but also appropriate local commitments through government policies. ${ }^{27}$ Countries are threatened from the sea and, although this threat historically shows a tendency to highlight the warfighting profile, the current African threat echoes the murky world of criminality, low-intensity threats and bad maritime governance. Ungoverned seas remain a danger to African states that have limited or no capacity to extend and uphold jurisdiction at sea and cannot police even soft maritime threats in a credible way. ${ }^{28}$ Africa's contribution to dominium over its seas thus remains limited and compromises good order at sea.

Partial governance of littoral waters goes a long way to promote order at sea with a maritime approach being of the essence. A maritime approach involves "Actions performed by military units in partnership with other government departments, agencies and interested partners in the maritime environment to counter illegal activity and support freedom of the seas for the protection of national and international interests". ${ }^{29}$ As a broad outline of maritime security, the aforementioned approach accentuates the multiplicity of actors and illegal activities at sea that in turn underline the imperative of upholding good order at sea. The description also alludes to threats and suggested partnerships to protect interests, and 
these two matters receive closer attention in the discussion below, which accentuates some detail of African maritime threats.

\section{African maritime threats}

Sageman (2010) and the abovementioned Brenthurst discussion paper (2010) both depict contemporary maritime threats residing or emerging off Africa. The 2010 AU maritime security workshop contributed to the debate on Africa's maritime security by stressing the need to address this neglected security domain. Amidst the piracy hype, a broader dialogue on understanding maritime threats in African waters is taking shape. The focus displayed in the literature remains, however, on the Horn of Africa and the Gulf of Guinea off West Africa, but the following maritime threats at times also reach beyond these two regions.

Terrorism

Luxor in Egypt (1997), Nairobi, Dar es Salaam (1998), Somalia (ongoing), Mombassa (2002), Uganda (2010), and Nairobi (2013) all attest to terrorism on African soil. At sea, the attacks on the USS Cole (2000) and MV Limburg (2002) in the Gulf of Aden are two incidents close to African waters, while the failed 2008 attack on the Shell Bonga oil platform off Nigeria remains noted due to its distance from land. ${ }^{30}$ Maritime terrorism off Africa is thus possible and a matter reinforced by lucrative targets at sea offering opportunities for economic destabilisation, punishment of governments tolerating lax coastal and portside security, and access of perpetrators to commercial technologies to operate at sea - all of which are reinforced by primarily questionable governmental practices facilitating bad order at sea. $^{31}$

Piracy

A number of developments promote the escalation in sea piracy as experienced by Africa. The growth in shipping traffic and its flow through choke points, in particular, turn the attention to the Bab el Mandeb off the Horn of Africa. The ongoing international economic crisis draws more people into maritime criminality - a matter only fuelling piracy on Africa's seas. Pressure for more landward security after the terrorist attacks of September 2001, over time drained resources away from maritime matters and eroded the means of upholding good order at sea. Africa already displays an undue fixation with landward security and thus increasingly tends to neglect maritime matters. Together with lax security measures in ports and coastal waters, official complicity in maritime crimes serves to reinforce the piracy threat. Africa unfortunately suffers from a general weakness in maritime governance (law enforcement in particular) that sustains piracy. ${ }^{32}$ Chalk 
views piracy more broadly as a triad comprising anchorage attacks, robberies against ships out at sea and theft of ships and cargo aimed at their conversion as 'phantom ships' for trade or pirate mother ships. ${ }^{33}$ Employed rather freely as a broad label for attacks on ships, piracy had become the face of Africa's maritime insecurity. Off the Horn of Africa, in the Gulf of Guinea and even further south, piracy continues to draw significant international attention. ${ }^{34}$

Illegal oil bunkering

Oil bunkering is most prevalent in Nigerian waters and holds national and international repercussions. Networks showing a criminal-rebel-government triad plague the Nigerian oil industry. The maritime connection plays out at sea through pirate tankers, receiving the stolen crude from criminal syndicates and transporting it further afield. ${ }^{35}$ A land-maritime connection operates between armed groups in the Niger delta, the maritime tanker syndicates and even corrupt naval/public officials reflecting interfaced criminality, political agendas and corrupt public officials. In the case of the 2003 MV African Pride incident in Lagos, the crew transferred the ship's illegal oil cargo to a pirate tanker at sea while under naval guard. ${ }^{36}$ While oil bunkering is largely criminal in kind, its intimate nexus with wider oil politics in the Niger delta region and a weakly policed Gulf of Guinea places illegal bunkering within the ambit of bad order at sea.

Drug trafficking

West Africa is a haven for drug trafficking from South America into Europe. The Atlantic Ocean serves as one transit route with little impediment from West African policing authorities. On the western edge of the Gulf of Guinea, Guinea Conakry offers a weakly policed maritime space, allowing drug syndicates (from the Caribbean and South America in particular) to move freely from the sea into West Africa. Geographic location and unstable political conditions alongside a tolerance for smuggling activities form attractive features for the drug traders. ${ }^{37}$ West Africa serves as a transit region for cocaine from South America into Europe and heroin from the Middle East to the USA. While Guinea Bissau appears to be the focal point, it masks Nigerian involvement in the drug trade through and from West Africa. ${ }^{38}$ Weak jurisdiction at sea tying in with a similar landward weakness facilitates drug trafficking from the sea into West African countries, and syndicates exploit this void to the full with indicators of a further link to the Tuaregs and even one suggestive of al Qaeda in the Maghreb connections. 
Smuggling

People wanting to leave Africa, or who are forced to do so by criminal syndicates face a journey by sea, whether across the Mediterranean or the Red $\mathrm{Sea} / \mathrm{Gulf}$ of Aden. Human trafficking and smuggling people who are desperate to leave the continent involve criminal syndicates in West Africa, North Africa and East Africa. ${ }^{39}$ Weapon smuggling takes place as well and often serves to fuel African armed conflicts. ${ }^{40}$ The large illegal arms shipment found in the port of Lagos in 2010 attests to suspicious or smuggled arms shipments through African waters and an incident not yet fully settled by the Nigerian and Iranian authorities. ${ }^{41}$ Pirates, poachers, armed militant groups and governments under international arms sanctions have a need for arms and thus offer a market for illegal arms shipments through weakly policed African waters.

Pollution

Rising pollution off the West African coast, off the South African coast, and potential pollution in the busy shipping lanes off the Horn of Africa are on record. The terrorist attack on the MV Limburg spilling oil into the Red Sea, waste dumping from the sea taking place into the interior of the Ivory Coast, and very dangerous toxic waste discovered on the Somali coast are some examples of deliberate maritime pollution. ${ }^{42}$ Within the lexicon of good order at sea, pollution threatens the African seas (as a source of food and an important environment) and in addition is a transgression perpetuated by rogue actors exploiting or sailing the seas and living on the shores. The threat affects African populations and their dependence upon pristine coastal waters as well as the right to live in an unpolluted coastal environment. Whether intentional or not, pollution is a constant threat in African waters with its weak or absent policing. The Brenthurst Foundation Discussion Paper is rather explicit about the pollution threat to the safety and security of Africa's seas - both for the seas as well as for its beneficiaries, entailing threats that affect areas much wider than the immediate coastal environments.

Unsettled maritime boundaries

The growing importance of the sea to African developmental and security futures is bound to question the status quo on maritime boundaries. As African attention moves offshore, unsettled maritime boundaries could well become contested. A host of maritime boundary disputes, unclear offshore demarcations and tentative agreements between parties are on record. West Africa shows a particularly unsettled profile commencing in the northwest between Morocco, Western Sahara and Mauritania regarding maritime boundaries. Further south, ongoing tribulations centre on the Gulf of Guinea and its littoral states. ${ }^{43}$ The DR Congo, Congo 
Brazzaville, and the Cabinda-Angola interface also reflect unsettled maritime boundaries in a known resource-rich offshore location. The maritime boundary between Namibia and South Africa seems to be tolerated, but the low-level dispute in the presence of gas, diamonds and possibly oil holds a certain conflict potential. ${ }^{44}$ Off the east coast, the maritime boundaries between South Africa, Mozambique and Madagascar straddle newly discovered gas deposits, while further north Kenya and Somalia also have not ironed out their maritime boundary. ${ }^{45}$ The majority of these boundary disputes and settlements unfold around marine resources of which oil and gas are catalysts of possible future interstate disputes. ${ }^{46}$

\section{Maritime security off West Africa}

The Gulf of Guinea is roughly demarcated by Angola in the south, and runs north towards Cameroon and then west via Nigeria towards Liberia and Sierra Leone on its western perimeter. It is a vast area populated by approximately 250 million people, includes the 500000 square miles Gulf of Guinea with rich hydrocarbon deposits, fish stocks and commercial shipping activities. ${ }^{47}$ Nigerian oil politics tends to dominate maritime threats and vulnerabilities off West Africa, but the threat landscape is more complex. Threats originate predominantly from volatility in the coastal states, ${ }^{48}$ as Nigeria, Equatorial Guinea, the Congo Republic, Sierra Leone and Liberia, for example, are known for their political turmoil that does not leave the littoral domain unscathed.

Competition between major powers over oil and gas in the Gulf of Guinea raises the possibility of armed confrontation - albeit something of the future - as the USA, Europe and Asia (China in particular) compete for energy resources. ${ }^{49} \mathrm{Big}$ power competition creates client states, and arming them to defend national interests indicates that the competition is no longer between multinational corporations only, but also between states. As state actors cloak energy security as a vital national interest, armed confrontation becomes more probable. Access to offshore oil and gas merges with the defence of energy security through armed confrontation, and the Gulf of Guinea as a future oil hub could increase militarisation in the region and in particular if maritime boundaries are unsettled as well. ${ }^{50}$ Equatorial Guinea, Nigeria and Ghana received or stand to receive new naval vessels, and it is not coincidental that these are countries with significant offshore oil and gas deposits, but also unsettled maritime boundaries. $^{51}$

Below the level of military confrontation, one finds offshore threats of a more irregular kind. Some threats flow from littoral countries like Nigeria; others enter from beyond the Gulf. Whether mere criminals or insurgents with politicoeconomic agendas or with terrorist intent, all threaten the maritime security of the 
Gulf region. Some threats, like theft, disrupt or exploit local port operations while piracy threatens vessels passing through these waters to offload or take on cargo with oil carriers increasingly becoming a target. ${ }^{52}$ Certain actors threaten the flow of oil or the offshore oil infrastructure, but pollution is also a serious matter in the region, with the Niger Delta creeks and fishing stocks heavily polluted and the region suffering from widespread illegal flaring. ${ }^{53}$

Insecure access to marine resources (oil, gas, fish, etc.), interrupted maritime traffic, and weak maritime jurisdiction by the littoral countries erode advantages of well-governed oceans to West African societies. Particularly salient is the absence of a credible regional capability to deal with threats towards or from the offshore domain. Rather large armies and police agencies reside on land, but naval and broader maritime capabilities, such as coastguards, remain marginal. ${ }^{54}$ The Gulf of Guinea thus reflects an array of maritime threats emanating from smuggling, oil bunkering, unsettled maritime boundaries, pollution and piracy to a land-maritime insurgent interface along Nigeria's coast in particular. Weak dominium at sea also allows transgressors to pursue their political and criminal agendas at sea unhindered with the most salient impact upon the extraction and harvesting of maritime resources (oil, gas and fishing) and those dependent upon safe maritime transport routes.

The aforementioned threats and vulnerabilities harbour an indelible maritime face and one noted by the UN (particularly its maritime agency, the International Maritime Organisation), the AU, international maritime organisations such as Intertanko, the International Maritime Bureau and important players such as the US and major oil corporations. ${ }^{55}$ Offshore threats in West Africa thus enjoy some status on governmental and non-governmental security agendas beyond the region, but the region is only one African hub of bad order at sea. The other serious maritime threat landscape resides off East Africa.

\section{Maritime security off East Africa}

The east African seaboard covers a maritime expanse from South Africa to the Gulf of Aden in the north and into the Red Sea up to Egypt. There are nine coastal states with several islands, such as Mauritius, the Grand Comoros, Madagascar, Zanzibar and the Seychelles, along this eastern littoral. Although not the only threat, piracy epitomises maritime insecurity along the African east coast. However, what observers tag as piracy is in fact a mix of attempted attacks, robberies and some piracy acts. ${ }^{56}$ By early 2011, several East African countries (Somalia, Kenya, Tanzania and Mozambique) experienced attacks within their

territorial waters. ${ }^{57}$ The sea around the Horn of Africa remains the focus with 97 
attacks reported in the first quarter of $2011{ }^{58}$ The ungoverned maritime space off Somalia merely reflects the long absence of any authority or governance on land, a void eventually filled in 2005 by the Transitional Federal Government (TFG) largely confined to Mogadishu. The insufficient governance that seeps from Mogadishu is unfortunately directed to landward matters, and except for statements, little gets done from Mogadishu about the maritime insecurity spreading from Somali waters southwards past Kenya to Mozambique and the Seychelles to the east. ${ }^{59}$

From a good-order-at-sea perspective, the seas off East Africa became a threat landscape with global repercussions, as free and uninterrupted maritime transport remains under attack. The number of attacks (237 attacks in 2011, dropping to 75 in 2012) ${ }^{60}$ and attempted hijacks underline the seriousness of the threat. A primary international sea route is almost under siege and the global shipping industry must cope with a semi-war zone on a strategic route between the Persian Gulf, Asia, Western Europe, Africa and the Americas. ${ }^{61}$ Commercial shipping and global maritime trade falling victim to attacks (or the persistent threat thereof) cause economic costs to soar through ransoms, delay times, cargoes on hold and similar matters. Threats to shipping do not impact externally only, but also affect countries in the region as trade through Suez (critical for Egypt) and important aid shipments en route to Africa (in the vicinity of the Horn in particular) are disrupted. $^{62}$

Beyond shipping and with regard to Somalia in particular, lawlessness at sea threatens human security. High incidences of piracy originating from Somali soil threaten and often curtail the supply of food for large displaced populations organised through the UN World Food Programme. Trade flows to Somalia and its neighbours come under threat as well while the movement of people attempting to leave Somalia by sea leads to loss of life. Maritime militias or pirates threaten a wide expanse of the Indian Ocean along the African east coast, and the growing number of vessels of all kinds attacked or hijacked reflect its impact. ${ }^{63}$

The landward impact of piracy requires attention as well, for it cannot be confined to Somalia. Somali piracy places strain upon the weak Somali government and affects neighbouring states negatively. The frequent interference with the shipping trade holds economic security implications for regional trade and its direct and indirect benefits for the region. Exports, vital imports and taxes from shipping become threatened - a loss African countries can ill afford. ${ }^{64}$ Threats to security spread over land as well as across the sea as depicted by the October 2011 Kenyan military action into southern Somalia. The maritime connection stems from the call by Kenya for a blockade of Kismayo in southern Somalia to pressure al-Shabaab, but at the beginning of 2011, the actions of Somali pirates also migrated as far south 
as the waters of Mozambique, to which the Southern African Development Community (SADC) responded with a naval task force.

The oceans off both East Africa as well as West Africa show a need for good order at sea as the threat spectrum reaches beyond that of piracy. Both maritime regions suffer from an apparent lack of applied maritime jurisdiction by the responsible governments bordering these regions and the following section attempts to highlight how threats and vulnerabilities are dealt with off Eastern and West Africa.

\section{Securitisation of two African maritime landscapes}

East and West Africa each harbours regions where threats at sea have drawn the attention of African as well as international decision-makers and nongovernmental agencies. Somalia and Nigeria play particularly significant roles as both countries harbour security threats and responses where the focus now includes the offshore domain.

East Africa

The international repercussions of threats to maritime activities off the Horn of Africa served to place Somali piracy on the UN Security Council (UNSC) agenda. In 2008, the wide support of UN member states allowed for the adoption of a number of UNSC resolutions that framed piracy as a threat and paved the way for international action - naval action in particular - against Somali piracy. The resolutions resulted in a large naval presence of non-African warships off the Horn of Africa. The naval contingents created a sense of security for the international community and its dependence upon secured maritime transport for trade ${ }^{65}$ and tied together a maritime consciousness and a response repertoire towards the threats off the Horn of Africa. Somalia perhaps most graphically displays an interface between landward and offshore responses to a growing and newly understood security landscape as piracy attacks have declined significantly by late $2012 .{ }^{66}$

International naval contingents off Somalia display an extraordinary response to the piracy threat. The US, NATO, the EU and individual states like Russia, China, India and South Korea maintain a naval presence around the Horn of Africa. Combined Task Force 151 emerged in January 2009, Allied Provider of NATO in October 2008, followed by Allied Protector in March 2009. In December 2008, Operation Atalanta of the European Union commenced. ${ }^{67}$ The naval response made the region's waters safer for merchant shipping through the Gulf of Aden in particular, but legislative voids and the geographic expanse allowed piracy to shift 
from the area under naval surveillance and thus raised the need for even greater international co-operation.

During late October 2011, Kenyan forces crossed into southern Somalia to curb the al-Shabaab threat to Kenya and called for the blockade of Kismayo harbour as a logistics conduit for al-Shabaab forces in the south. This inherently called for naval forces to block supplies by sea for al-Shabaab that extended maritime security beyond the piracy ambit. Kenya averred that al-Shabaab was dependent upon seaborne support that had to be interdicted - a matter accentuating a greater military response. ${ }^{68}$ Further south, however, South Africa began to patrol the northern waters of the SADC along the Mozambique-Tanzania maritime boundary by February 2011 by means of a small air-maritime task force. ${ }^{69}$ The South African reaction unfolded amidst persistent reports of a growing South African strategy to increase its naval capabilities to become more prominent in maritime operations off the African coast, although East Africa was bound to be the priority. ${ }^{70}$ A maritime strategy approved by the South African cabinet (22 April 2011) promised increased budgetary allocations (materialising in the 2013-2014 Budget Vote) and statements pointing to a growing South African naval presence in SADC waters in the south-western Indian Ocean. $^{71}$

Fundamental to the attempts to ensure good order at sea, co-operation remains pivotal - and not only in the state-naval realm. The 2008 UNSC resolutions reflect an international institutional response to maritime threats off the East African coast. In addition, the International Maritime Organisation (IMO) facilitated the Djibouti Code of Conduct in January 2009 with response centres planned for Kenya, Tanzania and Yemen. The Contact Group on Piracy off the Coast of Somalia (circa January 2009) represented a further attempt to establish co-operation to fight piracy as the main threat to maritime security off Somalia. The UN Office on Drugs and Crime also stepped in to help curb the growing threat at sea off East Africa. ${ }^{72}$ Several institutions thus co-operate to restore order at sea by creating frameworks for enforcing international law through international accords that deal with maritime safety and security.

The private security option raises images of armed contingents guarding ships en route through piracy hot spots. However, contributions by security contractors on land also play a role. ${ }^{73}$ Less visible and also less complicated than shipborne armed details, private security companies promote good order at sea by training and assisting maritime agencies on land in Somalia. Hart Security assisted Puntland to establish a coastguard that operated relatively successful against piracy, illegal fishing and smuggling at sea. ${ }^{74}$ As an example, Nordic Crisis Management (NCM) operated in Somaliland, and in particular around the port of Berbera, to 
provide training and security services to Somali authorities with the police, harbour security force and coastguard as clients. Advice and training, not operations against pirates, formed the focus of the security service by $\mathrm{NCM}^{75}$ However, the most direct private security intervention at sea stemmed from the announcement of a private navy (Convoy Escort Ltd) that was destined to begin escorting vessels through waters off the Horn of Africa by early 2012, and the growing prevalence of private armed guards on vessels - whether openly or more clandestine. ${ }^{76}$ Although controversial at times, the contributions of private security contractors have become a visible feature in promoting maritime security by protecting vessels, and training relevant maritime policing agencies in East Africa.

West Africa: The Gulf of Guinea

In West Africa, and in the Gulf of Guinea in particular, a patchwork of measures and actors is actively involved in promoting maritime security. While securitisation of East African offshore threats resulted in a strong naval response and mostly operates under a virtual UN umbrella, this is not the case off West Africa. A repertoire of military, institutional and private contributions is nonetheless discernible. In addition, a host of resolutions (amounting to 13 by 2010) collectively forms conduits for West African actors to address threats to maritime security, while about 24 conferences and workshops on matters related to West Africa's maritime domain took place between 2005 and $2010 .^{77}$ Resolutions and summits continued after 2010 as the Economic Community of Central African States and (ECCAS) and the Economic Community of West African States (ECOWAS) gathered to discuss the deteriorating situation in the Gulf of Guinea. Amongst these events the June 2013 summit in Yaounde, Cameroon, and UN Resolution 2039 (2012)on piracy in the Gulf of Guinea are perhaps the most significant developments. Maritime security thus features rather prominently in this region, but the threats and responses are different from those along the east coast.

Threats and vulnerabilities off West Africa connect with offshore resources, and security forces are often at the forefront of counter-measures. Resource diplomacy by interested parties shows some military overtures, with the US and China being the two lead actors. Several channels exist for funnelling arms and military skills into West Africa in an attempt to bolster local military capabilities to handle threats better. The US uses foreign military sales, military training and education programmes, as well as joint military exercises between West African navies and the US. China negotiates oil-for-arms deals with Gulf countries, but also with adjacent countries from which the arms flow to littoral countries on the Gulf. ${ }^{78}$ One important military actor is the US Africa Command (AFRICOM) with a presence in the Gulf of Guinea through its African Partnership Station programme. 
With a year-round naval presence in the Gulf region, the underlying sentiments remain that AFRICOM is primarily destined to help ensure US energy security off the coast of West Africa. ${ }^{79}$

The UN acknowledges the wider threat environment in West Africa and maritime insecurity in particular. ${ }^{80}$ The UN also calls for actions through a shared responsibility, but the focus seems to remain primarily within the landward realm. The UN noted, however, that an offshore threat to good order at sea exists, but the responses are more regional than UN-led. Several cooperative initiatives are visible - either suggested or in operation - but not so visibly under the aegis of the UN as found off the Horn of Africa.

The Gulf of Guinea Commission (GGC)

The GGC came into operation in 2006 (established 2001) to prevent, manage and resolve conflict between member states where offshore mineral resources become an issue. ${ }^{81}$ As a West African response, the GGC aims to prevent and resolve threats in a maritime region that could well house West Africa's future economic lifeblood. The Commission aims to resolve disputes about unsettled maritime boundaries that hold the potential of armed conflict if not resolved amicably. Together with the envisaged Gulf of Guinea Guard, the perceived outcome is a political as well as operational institution to consult and enforce, if necessary, matters pertaining to regional maritime security. ${ }^{82}$

Maritime Organisation of West and Central African States (MOWCA) ${ }^{83}$

Twenty coastal and five landlocked states form part of MOWCA, and the most significant contribution stems from attempts to establish a sub-regional coastguard, a regional maritime fund and communications centre. In co-operation with the IMO, MOWCA aims to create co-operative networks to enforce standing international arrangements better, to counter threats such as piracy, robberies and pollution, and to promote safety at sea through existing conventions. ${ }^{84}$ MOWCA represents the largest maritime security grouping in the region and as such acts as an umbrella organisation for a range of maritime actors and interested parties. ${ }^{85}$

Economic Community of West African States (ECOWAS)

The UN shows a preference for ECOWAS as the lead actor against security threats in West Africa, but a credible maritime capability through appropriate naval and coastguard assets remains weakly developed within its security architecture. ${ }^{86}$ Within the envisaged framework of the UN, co-operative ventures between ECOWAS, the AU, the UN Office on Drugs and Crime, as well as the UN Office in West Africa are more suitable conduits for action. Several instances of co-operation 
are already set in place to deal with threats and vulnerabilities in the region bordering the Gulf of Guinea. The UN, ECOWAS, the AU and AFRICOM (in spite of numerous obstacles such as mistrust and insufficient resources) show some progress for the imperative of cooperative or collaborative action against maritime threats.

Private security contractors

Foreign and local private security firms contribute visibly to maritime security in the Gulf of Guinea. Particularly relevant are the services offered to port and offshore facilities. Indigenous security arrangements provide services on land, while international security firms help to protect offshore infrastructure. ${ }^{87}$ One important driver of the growth in private security agencies in the region is an apparent lack of well-trained and properly equipped security forces - policing agencies in particular. ${ }^{88}$ The policing void amidst a security landscape calling for credible security establishments to offset criminal and other non-state threats is increasingly filled by the private security industry. ${ }^{89}$ In Nigeria, local and national private security companies represent a vibrant business sector. The oil sector shows the integration of governmental and private security agencies to protect this vital asset against attacks by groups harbouring political or criminal agendas. ${ }^{90}$ Private security services assume responsibility for offshore security by patrolling offshore and inland waterways together with elements of the Nigerian security forces. These security elements co-operate closely with Nigerian forces and expose them to the expertise of private contractors, and the latter learn more about the complex politics of the Niger delta region. ${ }^{91}$ From a training perspective, Military Professional Resources Incorporated, for example, trains a coastguard for Equatorial Guinea, and it appears that private companies are contracted to fill what seems to be a significant need for properly trained maritime security agencies, personnel and leaders. ${ }^{92}$

\section{Conclusions}

Africa's vast offshore domain is vitally important for the continent as well as the international community and a matter towards which African leaders and institutions are turning their attention. Piracy has sensitised both Africa and the international community to threats off Africa, but it also skewed the debate towards a problem-solving approach in the piracy-anti-piracy mould. Responses to piracy mask the general regression of good order at sea as depicted by possible terrorist threats, illegal oil bunkering, drug smuggling, illegal or unsafe resource exploitation, weak jurisdiction and the dangers of unsettled maritime boundaries. The more inclusive good-order-at-sea approach, however, raises a different set of questions 
and accommodates piracy within the wider field of responses informed by maritime security and maritime strategy respectively.

East and West Africa harbour multiple actions to restore good order at sea. Off East Africa, the Horn region in particular, extensive land and offshore actions by a host of parties integrate international and African initiatives that broadly fall under the aegis of the UN, private and African regional bodies. The different initiatives reside close to the maritime notion for they combine landward and offshore matters to address the interplay of measures at sea and on land for political, economic and humanitarian reasons. Off West Africa, and Nigeria in particular, landward politics play out explicitly in offshore threats. The responses result more from regional arrangements, co-operation and agreements to promote good order in the Gulf of Guinea and public-private partnerships. Both regions now begin to portray a response repertoire that reaches further than merely fighting piracy and a security landscape better understood along the lines of the imperative for good order. The latter approach offers scope for decision-makers to harness it as a vehicle to shift maritime security off Africa beyond the anti-piracy emphasis.

\section{Endnotes}

1 African Union. "Governance challenges in Africa and the role of the African Union". Public lecture to mark the $20^{\text {th }}$ anniversary of the European Centre for Development Policy Management, Maastricht, 19 December 2006, 6.

${ }^{2}$ McKinsey Global Institute. "Lions on the move: The progress and potential of African economies". Executive Summary, June 2010, 2.

${ }^{3}$ Mugridge, D. "Malaise or farce - The international failure of maritime security". Defence and Security Analysis 25/3. 2009. 305-311.

${ }^{4}$ Gilpin, R. "Enhancing maritime security in the Gulf of Guinea". Strategic Insights 6/1. January 2007. <http://www.nps.edu/Academics/centers/ccc/publications/OnlineJournal/200 7/Jan/gilpinJan07.pdf > Accessed on 28 November 2011.

${ }^{5}$ Heuser, B. The evolution of strategy: Thinking war from antiquity to the present. Cambridge: Cambridge University Press, 2010, 202.

${ }^{6}$ Wambua, PM. "Enhancing regional maritime security cooperation in Africa: The planned end state". African Security Review 18/3. 2010. 45-59.

7 Brenthurst Foundation. "Maritime development in Africa: An independent specialists' framework". Brenthurst Discussion Paper No 3. 2010. 7.

${ }^{8}$ United Nations, United Nations Convention on the Law of the Sea, 1982.

${ }^{9}$ Ibid., p. 10.

${ }^{10}$ Till, G. "Maritime strategy in a globalizing world". Orbis 51/4. 2007. 569-575. 
${ }^{11}$ Clark, D. Africa: The crude continent. The struggle for Africa's oil prize. London: Profile Books, 2008, 586.

${ }^{12}$ Africa Centre for Strategic Studies. See the Africa Security (Maritime Security) listing of the Africa Centre for Strategic Studies. <http://africacenter.org/security/topic/maritime-security/> Accessed on 16 November 2011.

13 African Union. "African Maritime Transport Charter". Second African Union Conference of Ministers Responsible for Maritime Transport, Durban, 1216 October 2009; African Union. "Durban Resolution on Maritime Safety, Maritime Security and Protection of the Marine Environment in Africa". Second African Union Conference of Ministers Responsible For Maritime Transport. Durban, 12-16 October 2009.

14 African Union. "AU's commitment to improve maritime security and safety". Press Release No 46/2010, 5 April 2010; African Union. "Maritime security and safety in Africa: Moving from talking to taking concrete action". Press Release No 47/2010, 6 April 2010.

${ }^{15}$ Brenthurst Foundation op. cit.

16 South African Government Communication and Information System (GCIS). "International Cooperation, Trade and Security". GCIS Media Briefing. 13 September 2011. <http://www.gcis.gov.za/newsroom/releases/briefings/2011/110913.htm> Accessed on 6 December 2011.

17 African Union. "AU Experts Workshop on Maritime Security and Safety". Presentation by the South African Navy, Africa's Strategy for Maritime Security: A SA Navy Perspective, Addis Ababa, 6 April 2010. <http://www.africa-union.org/root/ua/conferences/2010/avril/psc/07avril/ Maritime.htm> Accessed on 18 March 2010.

18 'Sea blindness refers to a socio-political failure to acknowledge or recognise the importance of the maritime domain to both society and economy'. See Mugridge op. cit., p. 306.

${ }^{19}$ Till, G. Seapower: A guide for the $21^{\text {st }}$ century. Oxford: Routledge, 2009, 286.

${ }^{20}$ Ibid., p. 287.

${ }^{21}$ Clark op. cit., p. 148.

${ }^{22}$ McKinsey Global Institute op. cit., p. 5.

${ }^{23}$ Tsvetkova, B. "Securing piracy off the coast of Somalia". Central European Journal of International Strategic Studies. 3/1. 2009. 44-63; Eyiwunmi Falaye. "Illegal, unreported, unregulated (IUU) fishing in West Africa 
(Nigeria and Ghana)". Report of a study for the Marine Resources Assessment Group, London, 2008, 1.

${ }^{24}$ Till, "Maritime strategy ..." op. cit., p. 571.

${ }^{25}$ Middleton, R. "Piracy in Somalia: Threatening global trade, feeding local wars". Chatham House Briefing Paper, AFP BP 08/02. October 2008. 3. <http://skuld.no/upload/News\%20and\%20Publications/Publications/Piracy/ Chatham\%20House\%20-\%20Piracy\%20in\%20Somalia.pdf > Accessed on 14 April 2011.

${ }^{26}$ United Nations, United Nations Convention on the Law of the Sea, 1982, as stated in the responsibilities of coastal states and the international community respectively.

${ }^{27}$ Till, "Maritime strategy ..." op. cit., p. 571.

${ }^{28}$ Brenthurst Foundation op. cit., p. 6.

${ }^{29}$ Till, Seapower ... op. cit., p. 287.

${ }^{30}$ Intertanko. "Shell's Bonga platform attacked and Chevron pipeline breached". 23 June 2008. <http://www.intertanko.com/templates/Page.aspx?id=44329> Accessed on 4 May 2011.

${ }^{31}$ Chalk, P. "The maritime dimension of international security: Terrorism, piracy and challenges for the United States". Santa Monica, CA: RAND Project Air Force, RAND Corporation, 2008, xiii.

${ }^{32}$ Chalk, op. cit., pp. xi-xii.

${ }^{33}$ The Sea Tigers of the LTTE movement in Sri Lanka, for example, acquired and employed ocean-going vessels as warehouse ships that kept the movement supplied from the sea for a number of years before their destruction and defeat of the LTTE by the Sri Lankan government forces in 2009.

34 International Maritime Organisation. "Reports on acts of piracy and armed robbery against ships". Annual Report 2010, MSC4/Circ. 169, 1 April 2011, 2 .

35 Davis, S, Von Kemedi, D \& Drennan, M. "Illegal oil bunkering in the Niger Delta". Niger Delta Peace and Security Strategy Working Papers. c2008. 11-12.

${ }^{36}$ Forrest, J \& Souza, M. Oil and terrorism in the new Gulf: Framing US energy and security policies for the Gulf of Guinea. Lexington, KY: Lexington Books, 2007, 100-101; Davis et al. op. cit., p. 12.

${ }^{37}$ Ellis, S. "West Africa's international drug trade". African Affairs 108/431. 2009. 170-196. 
${ }^{38}$ On 5 April 2013 the BBC reported that a former Chief of the Navy of Guinea Bissau, Rear Admiral J.A. Bubo, was arrested at sea in a drug sting operation and transferred to the United States to stand trial.

${ }^{39}$ Le Sage, A. "Africa's irregular security threats: Challenges for US engagement". Strategic Forum, Institute for National Security Studies, National Defence University, No 255, May 2010, 6.

${ }^{40}$ Brenthurst Foundation op. cit., p. 13.

${ }^{41}$ Radio Netherlands Worldwide: Africa. "Nigeria says latest arms shipment from Belgium". 25 November 2010. 〈http://www.rnw.nl/africa/bulletin/nigeriasays-latest-arms-shipment-belgiumaccessed $>$ Accessed on 15 April 2011.

${ }^{42}$ Brenthurst Foundation op. cit., p. 29; Le Sage op. cit., p. 7.

43 Daniel, T. "African maritime boundaries". In Colson, D \& Smith, R (eds), International maritime boundaries, Leiden/Boston: Brill Academic Publishers, 2005, 3429-3439.

${ }^{44}$ Ibid., pp. 3434-3435.

${ }^{45}$ Ibid., pp. 3435-3436.

${ }^{46}$ In 2009, the African Union appointed a naval officer from Ghana within their Border Programme to attend to maritime boundaries. I wish to thank a reviewer of the conference paper who pointed this out to me.

${ }^{47}$ Raidt, J \& Smith, K. "Advancing US, African and global interests: Security and stability in the West African maritime domain". Atlantic Council. 30 November 2010, 9.

48 Onuoha, F. "The geo-strategy of oil in the Gulf of Guinea: Implications for regional stability". Journal of Asian and African Studies 45/3. 2010. 369384; Raidt \& Smith op. cit., p. 9.

${ }^{49}$ Onuoha op. cit., p. 375.

${ }^{50}$ Ibid., p. 378.

51 “Ghana's navy receives four new patrol vessels". DefenceWeb. 26 October 2011; "Israel preparing to deliver two OPV to Equatorial Guinea Navy". DefenceWeb. 17 January 2011.

${ }^{52}$ Since 2012, hijacking of oil vessels in the Gulf of Guinea increased, although the reason for this is not yet clear.

53 Dadiowl, T. "Environmental impact assessment and sustainable development in the Niger Delta: The Gbarain Oil Field experience". Niger Delta Economies of Violence Working Papers Series 24. 2009. 3-4.

${ }^{54}$ Raidt \& Smith op. cit., p. 21.

55 See, for example, the United Nations Security Council Presidential Statement, which stresses the need for a comprehensive strategy to take on emerging 
threats in West Africa, Security Council SC/9702, SC $6160^{\text {th }}$ meeting, 10 July 2010, 1-2; Intertanko. Letter from Intertanko to the International Maritime Organisation on the attacks against merchant shipping in the Gulf of Guinea, 8 February 2009. Intertanko is an international organisation promoting the interests of the maritime tanker community.

${ }^{56}$ International Maritime Bureau. "Piracy and armed robbery against ships". Report for the period 1 January to 30 June 2009, July 2009, 3.

${ }^{57}$ Brenthurst Foundation op. cit., p. 13.

${ }^{58}$ International Chamber of Commerce. "Attacks off the Somali coast drive piracy to record high reports IMB". ICC Commercial Crime Services. 14 April 2011. < http://www.icc-ccs.org/news/441-attacks-off-the-somali-coast-drivepiracy-to-record-high-reports-imb > Accessed on 25 May 2011.

${ }^{59}$ It is important to note that the independent territories to the north, Somaliland, for example, show a more robust approach with a privately trained national maritime police force at play.

${ }^{60}$ International Chamber of Commerce, Piracy falls in 2012, but seas off East and West Africa remain dangerous says IMB, International Maritime Bureau Piracy Report, 16 January 2013.

${ }^{61}$ Brenthurst Foundation op. cit., p. 13.

${ }^{62}$ Ploch, L, Blanchard, C, O' Rourke, R, Mason, C \& King, R. "Piracy off the Horn of Africa". Congressional Research Service Report for Congress. Congressional Research Service, April 2009, 10-11.

${ }^{63}$ United Nations. "Report of the monitoring group on Somalia". Report pursuant to Security Council Resolution, 1853 S2010/91 of 2008, 10 March 2010, 35$36 ; 42-43$.

${ }^{64}$ Tsvetkova op. cit., pp. 50-51.

65 Bueger, C. "Security as performation: Securitization, piracy and the United Nations Security Council". Paper presented at the bi-annual conference of the Standing Group for International Relations of the ECPR, Stockholm, September 2010, 25-26.

${ }^{66}$ International Maritime Organisation. "Wide-ranging anti-piracy campaign bearing fruit”. IMO Press Briefing: Briefing 65. 16 December 2011.

<http://www.imo.org/MediaCentre/PressBriefings/Pages/65-piracy-yearend.aspx $>$ Accessed on 10 March 2013; United Nations. Report of the Secretary General pursuant to the Security Council Resolution (2020) 2011, 22 October 2012, 1.

${ }^{67}$ Ploch et al. op. cit., pp. 14-15. 
68 "Kenya sinks al Shabaab boats". DefenceWeb. 9 November 2009; "Big countries sought to help fight in Somalia". New York Times. 1 November 2011. A8.

${ }^{69}$ Department of Defence. "Speech by LN Sisulu, Minister of Defence and Military Veterans on the Occasion of the Department of Defence Budget Vote". Good Hope Chamber, Cape Town. 13 April 2011. <www.info.gov.za/speech/... > Accessed on 4 May 2012.

${ }^{70}$ Engelbrecht, L. “Cabinet: Piracy strategy approved?” DefenceWeb. 21 April 2011.

${ }^{71}$ Department of Defence op. cit.

${ }^{72}$ Ploch et al, op. cit., pp. 16-17.

73 International Maritime Organisation. "Interim guidance on use of privately contracted armed security personnel on board ships agreed by IMO Maritime Safety Meeting”. Maritime Safety Committee, $89^{\text {th }}$ session, 11-20 May 2011, Briefing 27. 20 May 2011. <http://www.imo.org/MediaCentre/ PressBriefings/Pages/27-MSC-89-piracy.aspx > Accessed on May 2011.

${ }^{74}$ Kinsey, C, Hansen, S \& Franklin, G. "The impact of private security companies on Somalia's governance networks". Cambridge Review of International Affairs 22/1. 2009. 147-161.

${ }^{75}$ Ibid., p. 155.

76 DefenceWeb, "Private navy to protect convoys". DefenceWeb. 10 November 2011.

${ }^{77}$ Raidt \& Smith op. cit., appendices IV \& V.

${ }^{78}$ Onuoha op. cit., pp. 378-379.

${ }^{79}$ Ibid., pp. $374-375$.

${ }^{80}$ United Nations Security Council. "Emerging security threats in West Africa". Security Council Report, Research Report No 1. May 2011. <http://www.securitycouncilreport.org/site/c.glKWLeMTIsG/b.6740225/k.7 43A/Research_Report_No_1brEmerging_Security_Threats_in_West_Africa brMay_2011.htm> Accessed on 29 November 2011.

${ }^{81}$ Onuoha op. cit., p. 380.

${ }^{82}$ Forrest \& Sousa op. cit., p. 222.

${ }^{83}$ By the middle of 2013, both MOWCA and the GGC participated in the growing efforts by ECCAS and ECOWAS (resulting in the Yaounde Declaration) to cooperate in response to the steep rise in attacks upon shipping (oil tankers in particular) in the Gulf of Guinea.

${ }^{84}$ Raidt \& Smith op. cit., p. 32.

85 See MOWCA detail on members, partners and projects at <http://www.mowca.org/ new\%20design/about-mowca.html > Accessed on 25 May 2011. 
${ }^{86}$ Raidt \& Smith op. cit., p. 32.

${ }^{87}$ Forrest \& Souza op. cit., pp. 202-203.

${ }^{88}$ On 10 September 2013, the US based private maritime security contractor AdvanFort announced that the government of Benin contracted the company to provide security services off Benin to protect vessels against attacks, robberies and hijacking.

${ }^{89}$ Ibid., p. 197.

90 Abrahamson, R \& Williams, M. "The globalization of security: Nigeria country report”. Globalization of Security Research Project, January 2005, 12-13.

${ }^{91}$ Ibid., p. 14.

${ }^{92}$ Forrest \& Sousa op. cit., p. 207. Also see Human Rights Watch. "Well oiled: Oil and human rights in Equatorial Guinea. Part VII: The role of the international community". 9 July 2009. <http://www.hrw.org/fr/node/84252/section/9> Accessed on 25 May 2011. 